languages and dialects to South America, Central America, the West Indies, Mexico, Europe, Africa and Asia. Inaugurated as a part of the Columbia Broadcasting System on January 1, 1942, the new station now operates regularly with three transmitters simultaneously consisting of two $50-\mathrm{kW}$. carriers, provided by new equipment designed and manufactured by the Federal Telephone and Radio Corporation, and the $10-\mathrm{kW}$. carrier of an older unit which was moved to Long Island from Wayne, New Jersey. The transmitters operate with a total of thirteen directive arrays, using nine frequencies from 6 to $22 \mathrm{mc}$. The antenna design provides a gain of 16 decibels over a conventional half-wave antenna in free space, due to the diroctional characteristics, making the effective radiation equivalent to almost $2,000 \mathrm{~kW}$.

The C.B.S. station is located on the 1,200-acre site of the Mackay Radio and Telegraph Company's overseas short-wave commercial radio stations on Long Island. In one case, the C.B.S. transmitters are operated on a Mackay antenna simultaneously with Mackay transmission. This is practicable since the type of antenna employed functions efficiently with more than one transmitter, provided the frequencies are separated by at least five per cent. All the C.B.S. transmitters are housed in a new, singlestory wing, $40 \mathrm{ft} . \times 60 \mathrm{ft}$., with basement, added to the existing Mackay transmitter building. Three exciters and three $50 \mathrm{~kW}$. final amplifiers aro provided. The additional radio frequency equipment allows the operators to pre set the frequency of one radio-frequency section while the other two radio frequency sections are being operated simultaneously. Instantaneous change-over to the pre set frequency may then be accomplished by operating the specially designed antenna switch. The transmitting equipment is described by H. Romander (Elec. Comm., 21, No. $2 ; 1943$ ) in an article which deals with the station layout, radio-frequency units, radio-frequency drivers, power amplifier, antenna switching mechanism, modulators, power frequeney equipment and control system. Photographs and circuit diagrams illustrate the article.

\section{Birth-rates in Germany}

According to the Journal of the American Medical Association of July 31, tho latest figures show a dramatic fall in the German birth-rate. In the large German eities the number of births in 1942 declined by 80,000 from 419,000 in 1940 , and the rate per thousand of population fell to 13.9 compared with 17.3 in 1940 . In the last quarter of 1942 the rate was as low as $12 \cdot 7$. The experience of the German. cities is borne out by the rate for all areas of Greater Germany, which declined from 20.4 during 1939-40 to $15 \cdot 2$ in 1942 , a loss of approxirnately 550, c00 livo births.

\section{Comet Comas-Sola}

A TELEGRAM from Lund announces that Miss Oterma has rediscovered Comet Comas-Sola very close to the position predicted by Messrs. Dinwoodie and Henderson in the "Handbook of the British Astronomical Association", 1943. Its magnitude is not indicated. An ephemeris for November is given below.

\begin{tabular}{|c|c|c|c|c|}
\hline $\begin{array}{c}\text { Date } 1943 \\
\text { Nov. } \\
4 \\
12 \\
20 \\
28\end{array}$ & $\begin{array}{cc} & \text { R.A. } \\
\text { h. } & \text { m. } \\
02 & 16 \cdot 3 \\
02 & 08 \cdot 3 \\
02 & 00 \cdot 9 \\
01 & 54 \cdot 7\end{array}$ & $\begin{array}{r}\text { Dec, } \\
+0^{\circ} 55^{\prime} \\
112 \\
143 \\
227\end{array}$ & $\begin{array}{c}r \\
2 \cdot 314 \\
2 \cdot 270 \\
2 \cdot 226 \\
2 \cdot 184\end{array}$ & $\begin{array}{l}P \\
1 \cdot 341 \\
1 \cdot 319 \\
1 \cdot 313 \\
1 \cdot 322\end{array}$ \\
\hline
\end{tabular}

\section{The Night Sky in November}

FuLL moon occurs on Nov. 12d. 01h. 36m. U.T., and new moon on Nov. $27 \mathrm{~d}$. $15 \mathrm{~h}, 23 \mathrm{~m}$. The following conjunctions with the moon take place: Nov. 14d. 10h., Mars $5^{\circ} \mathrm{N} . ;$ Nov, 14d. 21h., Saturn $2^{\circ}$ N.; Nov. 19d. 21h., Jupiter $0 \cdot 7^{\circ}$ S.; Nov. 23d. 18h., Venus $3^{\circ} \mathrm{S}$. The following occultations of stars brighter than magnitude 6 take place: Nov. 2d. 17h. $36 \cdot 8 \mathrm{~m}$., 115 B.Sgr $(D)$; Nov. 2d. 18h. 23.0m., 121 B.Sgr $(D)$; Nov. 15d. 01h. $5 \mathrm{l} \cdot 4 \mathrm{~m}, 57 \operatorname{Ori}(R)$; Nov. 18d. 0lh. $50.9 \mathrm{~m}$., $\theta$ (nc $(R)$. The times are given for Greenwich and $D$ and $R$ refer to disappearance and reappearance respectively. Mercury is a morning star at the beginning of the month, rising half an hour before the sun, and is in superior conjunction on Nov. 10. At the end of the month the planet rises at $9 \mathrm{~h}$. and sets at $16 \mathrm{~h} .13 \mathrm{~m}$. Venus is a morning star, rising at $2 \mathrm{~h} .40 \mathrm{~m}$. at the heginning of the month, and attaining its greatest westcrly elongation on Nov. 16 when it rices at $2 \mathrm{~h} .53 \mathrm{~m}$. At the end of the month it rises at $3 \mathrm{~h} .15 \mathrm{~m}$. Mars, an evening star in the constellation of Taurus, sets at $11 \mathrm{~h} ., 10 \mathrm{~h}$. and $8 \mathrm{~h}$. $4 \mathrm{~lm}$. at the beginning, middle and ond of the month respectively. Jupiter, in the constellation of Leo, rises just hefore midnight at the beginning of the month, and at $23 \mathrm{~h}$. $08 \mathrm{~m}$. and $22 \mathrm{~h}$. $15 \mathrm{~m}$. it the middle and end of the month respectively. Saturn is an evening star in the constellation of Taurus. The times of setting at the reginning, middle and end of the month are 1h. 0im., 10h. 08m. and 9h. 05m. respectively. The Leonid meteor shower is due on Nov. 13-14 and the Andromedid shower on Nov. 18-25, but for some years both these showers have keen very feeble and in some cases practically non-existent.

\section{Announcements}

THE thirtieth Thomas Hawksley Lecture of the Institution of Mechanical Engineers will be delivered by Prof. C. E. Inglis on November 15, at 5.30 p.m. He will speak on "Gyroscopic Principles and Applications".

THE Christmas Lectures at the Royal Institution, the hundred and fourteenth of the well-known series "adapted to a Juvenile Auditory", will bo delivered by Prof. E. N. da C. Andrade, Quain professor of physics in the University of London, who will speak on "Vibrations and Waves".

Lond Horder has been elected president of the British Association of Physical Mecticine.

The Rockefeller Foundation has made a grant of 7,500 dollars as a contribution to ho used by Prof. E'. F. Nord in commexion with his researches in enzyme shomistry at Fordham Unirersity, New York.

DR. L. E. C. Hughes has been appointed head of the Experimental Department of Messrs. Rediffusion, Ltd, at their works at Wandsworth. Dr. Hughes is technical editor of "Chambers' Technical Dictionary", of which a revised edition has recently appeared.

The Dominion Government of Canada has approved expenditure for establishing plants and equipment in Montreal and Toronto for the production of penicillin. The appropriation will cover the cost of creating the industry and that of the production of the first $20,000,000,000$ units of penicillin for use by the Canadian armed forces. The new industry, employing 250 men and women, will come into operation next February. 